\title{
STUDENT MISBEHAVIOR IN AGRICULTURAL EDUCATION: A COMPARATIVE STUDY
}

\author{
D. Barry Croom, Assistant Professor \\ Gary E. Moore, Professor \\ North Carolina State University
}

\begin{abstract}
This study examined the seriousness with which agriculture teachers view the misbehavior of students enrolled in their agriculture programs today and sought to determine if the level of seriousness of student misbehavior in agricultural education has changed over time. The participants in the study were 165 agricultural education teachers in North Carolina, South Carolina, and Virginia. These teachers rated 77 misbehaviors according to how serious a problem it created for them in their agriculture programs. No misbehaviors received a rating higher than 2.0 on a scale that had 4.0 as the critically disruptive behaviors, indicating that student misbehavior is not a serious problem in agricultural education. The most serious misbehavior manifested by students is a negative attitude toward school. However, there could be cause for concern when one realizes that the number one problem found in previous studies, "exhibiting an ambivalent attitude," slid to a $20^{\text {th }}$ place ranking. In this study, teachers perceive that students have finally made up their minds about school - they don't like it. The "love-hate" relationship reported by Burnett and Moore (1988) has essentially developed into a "hate" relationship.
\end{abstract}

\section{Introduction}

Ask parents to identify the problems facing schools today, and they are likely to respond that a lack of discipline among students is a serious problem (Rose \& Gallup, 2000). The public has identified discipline as a predominant problem in schools during the past 20 years and contends that stricter disciplinary measures are the essential factor in improving schools (Langdon \& Vesper, 2000). The public perceives that managing student behavior is an important component of the teacher's duty (Pestello, 1989).

Misbehavior as a Coping Mechanism

Maslow defined the attempt to solve problems or gain understanding of a situation for the purpose of satiating a need as coping behavior (Maslow, 1970). Coping behavior is purposeful, motivated, and often learned and usually causes changes in the student's environment (Maslow, 1970). By its very nature, coping behavior is based on external forces such as a response to an emergency or problem. In Maslow's words,
"It is an attempt to make up internal deficiencies by external satisfiers" (p. 132).

Coping may be expressed in a number of ways (Maslow, 1970). For instance, a student coping with a need for affiliation may choose to express foolish behavior in the classroom in an attempt to gain acceptance from his or her classmates. Another student coping with esteem needs might choose to work exceptionally hard on an assignment in order to earn a good grade and the favor of parents and teachers. Still another student who works a part-time job well into the late evening hours may cope with a physiological need for rest by being frequently absent from school (Dahl, 1999).

When coping violates the social norms within the classroom, we identify it as misbehavior (DeBruyn, 1983). When students misbehave, their academic performance suffers, and the misbehavior intensifies and becomes more frequent (Myers, Milne, Baker, \& Ginsburg, 1987). The methods by which educators attempt to modify or eradicate misbehavior can often result in an escalation of misbehavior or the appearance of other misbehaviors (Hyman, 
Weiler, Perone, Romano, Britton, \& Shanock, 1997). Students often react to corrective procedures in negative ways (Adelman \& Taylor, 1990). The result is a less effective teacher in the classroom (Ennis \& Silverman, 1996).

\section{The Role of the Teacher in \\ Managing Student Behavior}

There are three variables to misbehavior: the student with the problem, the environmental conditions under which the problem occurs, and the teacher (Debruyn, 1983). The variable that can be controlled with the greatest ease is the teacher's behavior. Thus, the teacher must not only diagnose the problem, but also take steps to adjust instruction and interaction with students to deplete the inappropriate behavior (DeBruyn, 1983; Palardy, 1995). Students recognize that teachers play a major role in curtailing inappropriate behavior through the employment of effective instructional activities (Supaporn, 2000; Doyle, 1986) Unfortunately, the physiological, cognitive, and moral dimensions to behavior make it difficult for instructors to diagnose and treat misbehavior (Blakeney \& Blakeney, 1990).

Recognizing the seriousness of behavior in the classroom is an essential part of teaching. Teacher preparation programs should understand the problems confronting teachers with regard to student misbehavior if instruction is to work and students are to learn. Providing teachers with valuable tools to manage student behavior effectively could slow the teacher attrition rate in agricultural education (Moore \& Camp, 1979).

Stebbins (1971) found that teachers rarely communicate among themselves to any depth about the subject of student misbehavior even though the stress generated by misbehavior was of greater concern than other working conditions (Abel \& Sewell, 1999). Because most teachers spend the majority of their workday almost exclusively with pupils, most teachers tend to formulate their own definition of misbehavior and handle those misbehaviors accordingly (Borg \& Riding, 1991). Thus, there is a wide range of behavioral modification techniques used to re-direct or repress certain types of behavior (Adelman \& Taylor, 1990).

This study replicates research by Camp and Garrison (1984) and Burnett and Moore (1988) on the perceptions of agriculture teachers as to the seriousness of misbehavior by their students. Camp and Garrison (1984) found that the student's attitude was a significant factor in misbehavior. Furthermore, the ambivalent attitude of students, students being poorly prepared for class, and a general negative student attitude were the most frequently cited behavioral problems (Camp \& Garrison, 1984). Burnett and Moore (1988) compared the perceptions of teachers in agricultural education to teachers in other vocational programs in Louisiana with regard to student misbehavior. Their study supported the findings of Camp and Garrison (1984). Agriculture teachers in Louisiana reported that students expressed ambivalent attitudes toward school. Students were also perceived to be inattentive and irresponsible, but these behaviors were not deemed to be a substantial disruption in class.

\section{Purpose}

The purpose of this study was to determine the level of seriousness at which agriculture teachers view the misbehavior of students enrolled in their agriculture programs in the 2000-01 school year. The study also attempted to determine if the level of seriousness of student misbehavior in agricultural education has changed over time.

\section{Procedures}

This descriptive study utilized a proportional sample of 121 instructors from North Carolina, 37 from South Carolina, and 90 from Virginia (Cochran, 1977). Teachers in these three states worked together to develop a strategic plan as part of the Reinventing Agricultural Education for the Year 2020 initiative, which serves as the rationale for including them in the study. The survey instrument developed and validated by Camp and Garrison (1984) served as the basis for instrument design. Additional refinements were made to the 
instrument based on the findings of Burnett and Moore (1988) and the instrument was validated by experts in agricultural education. The researchers collected demographic data and asked respondents to rate 77 behaviors according to how serious a problem they created for them in their respective agriculture programs. Two statements were added regarding the unauthorized use of the Internet and the presence of plagiarism in student work (Vernon, Bigna, \& Smith, 2001). The revised instrument generated a Cronbach's alpha of .98. The five-point rating scale ranged from 0 (Not a problem) to 4 (Critical - Behavior is unmanageable and instruction is halted). The agriculture teachers were mailed an introductory letter and survey instrument. Subsequent mailings to nonrespondents yielded a final response rate of $67 \% \quad(n=165$ respondents $)$ Early respondents $(n=127)$ were compared to late respondents $(n=38)$ for all variables in the study and no significant differences were found to exist (Miller \& Smith, 1983). The analysis of data began with the calculation of descriptive statistics. The next procedure involved a rank comparison of the mean scores of respondents in this study with the mean scores of respondents in the Burnett and Moore (1988) and Camp and Garrison (1984) studies.

\section{Findings}

Males made up $76 \%$ of the respondents. Teachers with a degree in agricultural education comprised the majority of respondents $(86.7 \%)$, and $48.5 \%$ had either earned an advanced degree beyond the baccalaureate level or had completed some type of post-baccalaureate work. One-third of all teachers in the sample $(n=109)$ held 12-month contracts. The largest groups of respondents taught in single-teacher programs $(42.4 \%)$ and two-teacher programs $(38.2 \%)$.

\section{The Level of Seriousness at Which Agriculture Teachers View Student Misbehavior}

Overall, teachers perceived student behaviors to be relatively easy to manage. The item with the highest mean score was that students have a negative attitude toward school $(M=1.88, S D=1.06)$. Only $8.5 \%$ of respondents $(n=14)$ indicated that this was serious enough to stop instruction. This behavior was followed closely by students talking without permission during a class or formal assembly $(M=1.85, S D=0.90)$ and the students' failing to take responsibility for their actions $(M=1.83, S D=0.97)$. Only $4.2 \%$ of respondents $(n=7)$ found talking to be a very serious problem and $5.4 \%$ of respondents $(n=9)$ saw their teaching halted by the irresponsibility of students. Teachers also ranked highly the students' failure to bring essential materials to class $(M=1.82$, $S D=.94)$. Eight teachers reported that the tendency for students to act in a clowning or foolish fashion was a serious problem $(M=1.73, S D=0.91)$. Teachers ranked certain passive misbehaviors higher than others, such as inattentiveness $(M=1.57, S D=.87)$ and a failure to complete in-class assignments $(M=1.53, S D=.87)$. Students also exhibited active misbehaviors such as interfering with the work of others $(M=1.55$, $S D=.79)$ and displaying hyperactivity $(M=1.51, S D=.84)$. On the scale used in the study, these ratings do not constitute serious misbehaviors. An examination of the frequency of responses by teachers in the study confirm these findings.

Students bringing pornographic materials to school $(M=.18, \mathrm{SD}=.38)$ was not a serious misbehavior. Teachers also reported a low frequency of students bringing unauthorized persons onto campus $(M=.26, S D=.49)$. Other behaviors that occurred with such low frequency and intensity that they were unlikely to be a problem include political activism by students $(M=.11, S D=.46)$ and their participation in unauthorized political protests $(M=.007 ; S D=.32)$. Very serious behaviors such as murder or attempting to commit murder $(M=.005 ; S D=0.44)$, and committing rape or attempting rape $(M=.008 ; S D=.48)$ also occurred at a very low frequency. Table one lists the behaviors observed by respondents.

\section{The Relationship Between the Findings of}

This Study and Those of Previous Studies

Spearman's Rho was calculated for the relationship between this study and the two 
previous studies on student misbehavior in agricultural education. The mean scores for each study were ranked, then compared. There was a very strong relationship $(\rho=.916)$ between the misbehavior rankings of this study and those of Burnett and Moore (1988). A similar relationship $(\rho=.902)$ exists between this study and the findings of Camp and Garrison (1984). A stronger relationship $(\rho=.973)$ was found to exist between the Camp and Garrison (1984) and the Burnett and Moore (1988) study. All relationships were significant $(p<.01)$.

Even though these studies are strongly correlated, which indicates most of the behaviors were ranked about the same today as they were in the past, a visual observation of the data revealed that 14 behaviors had noticeably different rankings today than they did 14 and 16 years ago. A noticeably different behavior was defined by the researchers as moving 15 or more positions in the ranking in the 2000 study as compared to the mean ranking of the previous two studies. Nine behaviors had risen in the rankings while five had decreased.

\section{Behaviors That Are Climbing in the Rankings}

"Displaying abnormally active behavior" was ranked $11^{\text {th }}$ in this study. This behavior was ranked $36^{\text {th }}$ and $43^{\text {rd }}$ in the previous two studies. "Failing to submit homework in a timely manner" now ranks $14^{\text {th }}$ instead of $31^{\text {st }}$ and $32^{\text {nd }}$ as it did earlier. In the previous studies, "consuming chewing gum, candy, food and/or beverages" was ranked $37^{\text {th }}$ and $41^{\text {st }}$. Today it ranks $17^{\text {th }}$. The remaining behaviors that changed rankings are not in the top 20; however, a discernable trend over the three studies can be seen. In 1984 "violating the school dress code" ranked $68^{\text {th }}$, in 1988 the ranking was $50^{\text {th }}$, and today it is $39^{\text {th }}$. "Causing racial or ethnic disturbances" moved from $72^{\text {nd }}(1984)$ to $66^{\text {th }}(1988)$ to $50^{\text {th }}$ in 2000 . Two related behaviors also rose in the rankings. "Inappropriately displaying affection (body contact)" is now ranked $44^{\text {th }}$. This behavior was ranked $64^{\text {th }}$ and $62^{\text {nd }}$ in the previous two studies. "Displaying inappropriate sexual behavior" moved from $81^{\text {st }}$ in the previous two studies to $54^{\text {th }}$ in 2000 . The two other behaviors that rose in the rankings were "sleeping in class" which rose from $58^{\text {th }}$ and $59^{\text {th }}$ in the previous two studies to $36^{\text {th }}$ today and "verbally confronting authorities" which went from $53^{\text {rd }}$ and $45^{\text {th }}$ to $34^{\text {th }}$ today.

\section{Behaviors That Declined in the Rankings}

In the 1984 and 1988 studies, the number one misbehavior was "exhibiting an ambivalent attitude." That statement was rated $20^{\text {th }}$ in the 2000 study. "Smoking or chewing tobacco in any form" was ranked $11^{\text {th }}$ and $9^{\text {th }}$ in the previous studies. This behavior was ranked $26^{\text {th }}$ in the current research. "Vandalizing school property" has dropped to $32^{\text {nd }}$ from $16^{\text {th }}$ and $17^{\text {th }}$ place in the two previous studies. "Committing minor theft" also dropped. In 1984 this behavior ranked $21^{\text {st }}$, in 1988 it ranked $31^{\text {st }}$, and in 2000 it ranked $46^{\text {th }}$. A surprising finding to the researchers was the ranking of "failing to maintain clean work or study area." In the previous studies this misbehavior was ranked $6^{\text {th }}$ in 1984 and $3^{\text {rd }}$ in 1988. In the 2000 study, this misbehavior was ranked $27^{\text {th }}$.

\section{Misbehavior as an Over-arching Theme}

A scale mean of $75.80(S D=37.68)$ was computed from teachers' responses as well as an item mean of .98 $(S D=0.51)$. Thus, teachers have average item scores of slightly less than 1 on a scale of 0 to 4 . This study found student misbehavior, while a common theme among teachers, does not cause more than a minimal disruption during class. 
Table 1

The Description of Misbehaviors and Their Rank and Mean

\begin{tabular}{|c|c|c|c|c|c|c|}
\hline \multirow[t]{2}{*}{ Description } & \multicolumn{2}{|c|}{$\begin{array}{c}\text { Present Study } \\
n=165\end{array}$} & \multicolumn{2}{|c|}{$\begin{array}{c}1988 \text { Study } \\
n=75\end{array}$} & \multicolumn{2}{|c|}{$\begin{array}{c}1984 \text { Study } \\
n=437\end{array}$} \\
\hline & M & Rank & M & Rank & M & Rank \\
\hline Having a negative attitude toward school. & 1.88 & 1 & 1.97 & 2 & 1.93 & 3 \\
\hline Talking without permission. & 1.85 & 2 & 1.89 & 5 & 1.85 & 4 \\
\hline Failing to assume responsibility for actions. & 1.83 & 3 & 1.69 & 10 & 1.49 & 12 \\
\hline Failing to bring necessary materials to class. & 1.82 & 4 & 1.96 & 4 & 2.04 & 2 \\
\hline Displaying clownish and foolish behavior. & 1.73 & 5 & 1.89 & 7 & 1.66 & 7 \\
\hline Failing to follow instructions. & 1.68 & 6 & 1.89 & 6 & 1.77 & 5 \\
\hline Inattentiveness during class. & 1.57 & 7 & 1.53 & 20 & 1.45 & 15 \\
\hline Interfering with work of others. & 1.55 & 8 & 1.51 & 23 & 1.53 & 10 \\
\hline Failing to do in-class assignments. & 1.53 & 9 & 1.60 & 14 & 1.55 & 8 \\
\hline Being disrespectful toward other students. & 1.53 & 10 & 1.60 & 15 & 1.48 & 13 \\
\hline Displaying abnormally active behavior. & 1.51 & 11 & 1.23 & 36 & 0.99 & 43 \\
\hline Using profanity/abusive language. & 1.50 & 12 & 1.64 & 12 & 1.53 & 11 \\
\hline Absenteeism (truancy). & 1.49 & 13 & 1.69 & 9 & 1.37 & 18 \\
\hline Failing to submit homework on time. & 1.48 & 14 & 1.29 & 32 & 1.19 & 31 \\
\hline Teasing others. & 1.46 & 15 & 1.52 & 21 & 1.35 & 20 \\
\hline
\end{tabular}


$\underline{\text { Table } 1 \text { Continued }}$

The Description of Misbehaviors and Their Rank and Mean

\begin{tabular}{|c|c|c|c|c|c|c|}
\hline \multirow[t]{2}{*}{ Description } & \multicolumn{2}{|c|}{$\begin{array}{c}\text { Present Study } \\
\quad n=165\end{array}$} & \multicolumn{2}{|c|}{$\begin{array}{c}1988 \text { Study } \\
n=75\end{array}$} & \multicolumn{2}{|c|}{$\begin{array}{c}1984 \text { Study } \\
n=437\end{array}$} \\
\hline & $M$ & Rank & $M$ & Rank & $M$ & Rank \\
\hline Making inappropriate comments to others. & 1.45 & 16 & 1.57 & 17 & 1.25 & 27 \\
\hline Consuming food and/or beverages. & 1.44 & 17 & 1.23 & 37 & 1.05 & 41 \\
\hline Being dishonest toward teachers and others. & 1.44 & 18 & 1.76 & 8 & 1.28 & 23 \\
\hline Being disrespectful toward authorities. & 1.43 & 19 & 1.51 & 27 & 1.31 & 22 \\
\hline Exhibiting an ambivalent attitude. & 1.38 & 20 & 2.01 & 1 & 2.13 & 1 \\
\hline Abusing privileges. & 1.35 & 21 & 1.51 & 26 & 1.30 & 28 \\
\hline Failing to submit homework at all. & 1.35 & 22 & 1.51 & 24 & 1.46 & 14 \\
\hline Being tardy to school. & 1.35 & 23 & 1.51 & 28 & 1.27 & 24 \\
\hline Being tardy to class. & 1.34 & 24 & 1.56 & 18 & 1.36 & 19 \\
\hline Cheating on tests and in-class assignments. & 1.33 & 25 & 1.61 & 13 & 1.25 & 26 \\
\hline Smoking or chewing tobacco. & 1.32 & 26 & 1.69 & 11 & 1.54 & 9 \\
\hline Failing to maintain a clean work area. & 1.3 & 27 & 1.97 & 3 & 1.73 & 6 \\
\hline Passively evading instruction/authority. & 1.25 & 28 & 1.20 & 38 & 1.19 & 30 \\
\hline Skipping class. & 1.22 & 29 & 1.25 & 35 & 1.09 & 37 \\
\hline Throwing objects. & 1.22 & 30 & 1.28 & 34 & 1.09 & 38 \\
\hline Plagiarizing the work of others. & 1.21 & 31 & - & - & - & - \\
\hline Vandalizing school property. & 1.20 & 32 & 1.59 & 16 & 1.40 & 17 \\
\hline
\end{tabular}




\section{Table 1 Continued}

\begin{tabular}{|c|c|c|c|c|c|c|}
\hline \multirow[t]{2}{*}{ Description } & \multicolumn{2}{|c|}{$\begin{array}{c}\text { Present Study } \\
n=165\end{array}$} & \multicolumn{2}{|c|}{$\begin{array}{c}1988 \text { Study } \\
n=75\end{array}$} & \multicolumn{2}{|c|}{$\begin{array}{c}1984 \text { Study } \\
n=437\end{array}$} \\
\hline & $M$ & Rank & $M$ & Rank & $M$ & Rank \\
\hline Moving without the instructor's permission. & 1.19 & 33 & 1.52 & 22 & 1.17 & 34 \\
\hline Verbally confronting authorities. & 1.16 & 34 & 1.01 & 53 & .96 & 45 \\
\hline Openly refusing to comply with instructions & 1.13 & 35 & 1.17 & 40 & 1.03 & 42 \\
\hline Sleeping in class. & 1.13 & 36 & .92 & 58 & .61 & 59 \\
\hline Antagonizing others (bullying). & 1.13 & 37 & 1.29 & 33 & 1.20 & 29 \\
\hline Slovenly manner/appearance. & 1.13 & 38 & 1.20 & 44 & .96 & 44 \\
\hline Violating the school dress code. & 1.09 & 39 & 1.08 & 50 & .40 & 68 \\
\hline Writing or making derogatory comments. & 1.07 & 40 & 1.12 & 43 & .67 & 57 \\
\hline Running in hallways and instructional areas. & 1.07 & 41 & 1.16 & 41 & .96 & 46 \\
\hline Reading non-instructional materials in class. & 1.06 & 42 & 1.09 & 48 & 1.10 & 36 \\
\hline Making obscene gestures. & .93 & 43 & 1.20 & 45 & .91 & 49 \\
\hline Inappropriately displaying affection. & .92 & 44 & .79 & 64 & .52 & 62 \\
\hline Destroying property. & .92 & 45 & 1.16 & 42 & 1.07 & 39 \\
\hline Committing minor theft. & .91 & 46 & 1.37 & 31 & 1.31 & 21 \\
\hline Leaving the school without permission. & .84 & 47 & 1.07 & 52 & .79 & 51 \\
\hline Vandalizing community property. & .82 & 48 & 1.19 & 39 & 1.06 & 40 \\
\hline Threatening other students. & .81 & 49 & 1.20 & 46 & .74 & 53 \\
\hline
\end{tabular}

$\underline{\text { Table Continues }}$ 
$\underline{\text { Table } 1 \text { Continued }}$

\begin{tabular}{|c|c|c|c|c|c|c|}
\hline \multirow[t]{2}{*}{ Description } & \multicolumn{2}{|c|}{$\begin{array}{c}\text { Present Study } \\
\quad n=165\end{array}$} & \multicolumn{2}{|c|}{$\begin{array}{c}1988 \text { Study } \\
n=75\end{array}$} & \multicolumn{2}{|c|}{$\begin{array}{c}1984 \text { Study } \\
n=437\end{array}$} \\
\hline & $M$ & Rank & $M$ & Rank & $M$ & Rank \\
\hline Causing racial or ethnic disturbances. & .78 & 50 & .73 & 66 & .32 & 72 \\
\hline Entering prohibited areas at school. & .65 & 51 & .80 & 61 & .53 & 60 \\
\hline Using drugs before school (e.g., marijuana). & .63 & 52 & 1.01 & 54 & .75 & 52 \\
\hline Consuming alcoholic beverages. & .63 & 53 & .99 & 56 & .63 & 58 \\
\hline Displaying inappropriate sexual behavior. & .62 & 54 & .32 & 81 & .08 & 81 \\
\hline Hitting/injuring other students. & .59 & 55 & .99 & 55 & .89 & 50 \\
\hline Unauthorized use of the Internet. & .58 & 56 & - & - & - & - \\
\hline Passing notes in class. & .58 & 57 & .69 & 69 & .44 & 65 \\
\hline Selling illegal drugs. & .48 & 58 & .72 & 68 & .36 & 71 \\
\hline Using drugs at extracurricular activities. & .48 & 59 & .99 & 57 & .74 & 54 \\
\hline Committing major theft. & .45 & 60 & .89 & 60 & .70 & 55 \\
\hline Consuming/possessing alcoholic beverages. & .45 & 61 & 1.2 & 47 & .92 & 48 \\
\hline Smoking marijuana at school. & .45 & 62 & .8 & 63 & .69 & 56 \\
\hline Gambling or gaming in any form. & .43 & 63 & .55 & 73 & .39 & 69 \\
\hline Using illegal drugs other than marijuana. & .39 & 64 & .8 & 62 & .49 & 64 \\
\hline Exhibiting socially delinquent behavior. & .36 & 65 & .48 & 77 & .23 & 77 \\
\hline Threatening school employees. & .34 & 66 & .53 & 75 & .23 & 76 \\
\hline
\end{tabular}




\section{Table 1 Continued}

\begin{tabular}{lcccccc}
\hline Description & $\begin{array}{c}\text { Present Study } \\
n=165\end{array}$ & $\begin{array}{c}\text { 1988 Study } \\
n=75\end{array}$ & $\begin{array}{c}\text { 1984 Study } \\
n=437\end{array}$ \\
& $M$ & Rank & $M$ & Rank & $M$ & Rank \\
\hline Bringing weapons to school. & .32 & 67 & .68 & 70 & .3 & 73 \\
Bringing unauthorized persons to campus. & .26 & 68 & .92 & 59 & .5 & 63 \\
Stealing testing materials. & .26 & 69 & .64 & 72 & .25 & 75 \\
Intentionally injuring oneself. & .24 & 70 & .27 & 85 & .09 & 79 \\
Inciting a riot or mob action. & .20 & 71 & .67 & 71 & .43 & 66 \\
Striking or injuring school employees. & .18 & 72 & .41 & 78 & .13 & 78 \\
Bringing pornographic materials to school. & .18 & 73 & .52 & 76 & .26 & 74 \\
Participating in unauthorized political & .11 & 74 & .17 & 86 & .05 & 85 \\
activism on campus. & & & & & & \\
Committing rape or the intent to rape. & .008 & 75 & .28 & 84 & .05 & 86 \\
Participating in unauthorized protests. & .007 & 76 & .3 & 82 & .09 & 80 \\
Committing murder or attempted murder. & .005 & 77 & .36 & 80 & .06 & 84 \\
\hline
\end{tabular}

\section{Conclusions/Discussion/Implications}

The good news is that agricultural education students are not running rampant through the halls of the schools. Generally, those students under the supervision of agriculture teachers are manifesting behavior that meets commonly accepted norms. None of the misbehaviors received a rating higher than 2.0 on a scale that had 4.0 as representative of the critically disruptive behaviors. This indicates that student misbehavior is not a serious problem in agricultural education and that instruction is, at most, minimally disrupted. The level of seriousness at which agriculture teachers view student misbehavior has not changed significantly over time. A comparison of the results of this study with the last two major studies of student misbehavior in agricultural education finds that teacher perceptions of the seriousness of student behavior are relatively stable. Even though some people may believe student misbehavior is getting worse, the data do not support that view.

The most serious behavior manifested by students in the year 2000 is a negative attitude toward school. This same behavior existed in 1988 (ranked $2^{\text {nd }}$ ) and in 1984 (ranked $3^{\text {rd }}$ ). However, there could be cause for concern when one realizes the previous 
number one problem in 1984 and 1988 "exhibiting an ambivalent attitude" slid to a $20^{\text {th }}$ place ranking. Is the "I don't care" attitude being replaced by a decidedly negative attitude? Students who exhibit an ambivalent attitude toward school generally have no polar opinion about school - they are unsure. It seems that in the 14 years since the last study on student misbehavior in agricultural education, teachers perceive that students have finally made up their minds about the institution of learning - they don't like it. The "love-hate" relationship reported by Burnett and Moore (1988) has essentially developed into a "hate" relationship.

The implications of a negative attitude toward school may be manifested in several other misbehaviors that have also risen in the rankings. Failing to submit homework in a timely manner, displaying abnormally active behavior, verbally confronting authorities, and violating the school dress code have all risen 15 or more positions since the Burnett and Moore (1988) and Camp and Garrison (1984) studies. Having a negative attitude toward school could influence these behaviors.

Of the noticeable changes in behavior, one is gratifying. Teachers reported that tobacco use has declined among agricultural education students. This finding is supported by a recent national study by the Centers for Disease Control and Prevention (2001) that reports teen smoking rates have leveled off or are declining for the first time in years. According to the $\mathrm{CDC}$ report, teen smoking rates decreased from $36.4 \%$ in 1997 to $34.8 \%$ in 1999 , although smoking rates for female high school students remain essentially unchanged (Centers for Disease Control and Prevention [CDC], 2001). The findings of this research support the CDC (2001) findings.

The decline in tobacco use may be offset by the increase in food and beverage consumption in the classroom. This misbehavior increased 22 places in the rankings. The increase in food and beverages consumed by students in the classroom may be the result of a school system's attempt to fund educational initiatives with lucrative soft drink sales contracts. Many schools use special sales agreements with major soft drink companies to landscape schools and sponsor academic programs and sports activities. The presence of soft drink retailers in schools is increasing as companies seek to increase the number of drink machines and serving sizes (Jacobson, 2001). While the sale of drinks at school may help the school coffers, it might be contributing to increased misbehavior.

Jacobson (2001) found that 25\% of teenage boys are consuming an average of 30 ounces of soft drink per day and $25 \%$ of teenage girls drink 25 ounces of soft drink daily. This increased consumption of soft drinks may influence hyperactivity among students. Some high school students may be consuming 22 to 53 milligrams of caffeine per day (Jacobson, 2001). A recent study by Bernstein (2001) found that some children exhibited signs of nervousness and hyperactive behavior as a result of caffeine consumption. This might help explain the rise of "displaying abnormally active behavior," which now ranks 11th as a problem. This is up nearly 30 places from the previous two studies.

Teachers in this study reported that inappropriate sexual activity among students was more of a problem for them than their colleagues in the previous two misbehavior studies. Changing social norms may be pressuring students into sexual activity before they are prepared for the consequences of such activity. In spite of numerous education and prevention programs, the problem of sexual activity in teens does not show signs of abating. According to the Centers for Disease Control and Prevention (1998), nearly one-half of high school students have had sexual intercourse.

\section{Implications and Recommendations}

There are several implications and recommendations that arise from this research.

\section{Teacher Recruitment}

Some potential teachers (e.g., former state FFA officers, people with agricultural degrees working in industry) have considered becoming certified to teach but 
have decided against teaching because they don't want to handle all those "unruly high school students." The reality is that the misbehaviors teachers can expect to handle are rather minor. This needs to be communicated clearly to potential teachers. The public perception that schools are out of control is not an accurate picture.

\section{Teacher Training}

In our teacher education classes, we need to instruct our students about the types of misbehaviors they can realistically expect to encounter while teaching. We should also provide them with suggestions and strategies for handling the most urgent misbehaviors. If student teachers know in advance that their students may have a negative attitude, will talk without permission, will clown around, etc., then they will be less inclined to take the problem personally and think they are the only ones with these types of problems. Student teachers will expect these situations and be better prepared to handle them. It appears that teacher educators are doing a good job in this regard since the severity of the problems has not increased, but has actually declined slightly over the past $14-16$ years.

\section{Inservice Education}

When planning inservice education activities for teachers, education officials might want to consider planning activities based on some of the trends identified in this research. With the changing demographics of the population, it might be wise to consider how to work with multicultural populations and promote inclusion within the classroom. Teachers may also need guidance with regard to handling the increasing prominence and display of sexual conduct on the part of students.

Three suggestions are offered for further research:

Study the function of misbehavior

Denti (2002) suggests that misbehavior can be measured in four dimensions: form, frequency, duration, and intensity. This theory was not used in this study because the researchers chose to maintain consistency with two previous studies. This was necessary in order to make useful comparisons among the three studies. However, research on the function of misbehavior has merit and should be considered for further research.

\section{Investigate Student Perceptions of Misbehaviors}

This study and the previous two asked agricultural teachers for their perceptions of student misbehaviors. It might be informative to ask the students. Do they identify the same behaviors as the teachers? Do they believe that these misbehaviors actually interfere with their ability to learn?

\section{Investigate the Effects of Gender and Ethnicity and Other Demographic Characteristics on Teachers' Opinions of Misbehavior}

It would be informative to determine if teacher age and experience level, gender, and school characteristics such as school size and length of class period have an effect on student behavior.

\section{References}

Abel, M.H., \& Sewell, J. (1999). Stress and burnout in rural and urban secondary school teachers. Journal of Educational Research, 92, 287-294.

Adelman, H.S., \& Taylor, L. (1990). Intrinsic motivation and school misbehavior: Some intervention implications. Journal of Learning Disabilities, 23 (9), 541-550.

Bernstein, G. (2001). A surge in popularity. University of Minnesota TC News Tips, Retrieved January 5, 2002 from: http://www1.umn.edu/urelate/tips/5-597.html.

Blakeney, C., \& Blakeney, R. (1990). Reforming moral behaviour. Journal of Moral Education, 19(2), 101-114.

Borg, M.G., \& Riding, R.J. (1991). Stress in teaching: A study of occupational stress and its determinants, job satisfaction and career commitment among primary schoolteachers. Educational Psychology, 11(1), 59-77. 
Burnett, M.F., \& Moore, G.E. (1988). Student misbehavior in vocational agriculture and other vocational programs: A comparison. Proceedings of the $15^{\text {th }}$ National Agricultural Education Research Meeting, St. Louis, MO, 15, 42-47.

Camp, W.G., \& Garrison, J.M. (1984). The seriousness of student misbehavior in vocational agriculture. Journal of the American Association of Teacher Educators in Agriculture, 25(1), 42-47.

Centers for Disease Control and Prevention. (2001, August). Tobacco information and prevention source. Retrieved December 12, 2001 from: http://www.cdc.gov/ tobacco/youth.htm.

Centers for Disease Control and Prevention. (1998, August). Morbidity and mortality weekly report: Youth risk behavior surveillance, 1997. Retrieved December 11, 2001 from://ftp.cdc.gov/pub/ Publications /mmwr/SS/ SS4703.pdf.

Cochran, W.G. (1977) Sampling techniques. New York, NY: Wiley.

Dahl, R.E. (1999). The consequences for insufficient sleep for adolescents. Phi Delta Kappan, 80, 354-360.

DeBruyn, R.L. (1983). Before you can discipline: Vital professional foundations for classroom management. Manhattan, KS: Master Teacher, Inc.

Denti, L. (2002). Behavior intervention and support module: Functional behavioral analysis. Alternative Education Website. Retrieved March 31, 2002 from http: http://alternativeed.sjsu.edu/.

Doyle, W. (1986). Classroom organization and management. In M.C. Whittrock (Ed.), Handbook of Research on Teaching (pp. 329-431). New York, NY: Macmillan.

Ennis, C.D., \& Silverman, S.J. (Eds.). (1996). Student learning in physical education: Applying research to enhance instruction. Champaign, IL: Human Kinetics.

Hyman, I., Weiler, E., Perone, D., Romano, L., Britton G., \& Shanock, H. (1997). Victims and victimizers: The two faces of school violence. In A.P. Goldstein, \& J.C. Conoley (Eds.), School violence intervention: A practical handbook. New York, NY: The Guilford Press.

Jacobson, M. (2001). Liquid candy: How soft drinks are harming Americans' health. Retrieved January 5, 2002 from: http://www.cspinet.org/sodapop/liquid_cand y.htm

Langdon, C. A., \& Vesper, N. (2000, April). The sixth Phi Delta Kappa poll of teachers' attitudes toward the public schools. Phi Delta Kappan, 81, 607-611.

Maslow, A. (1970). Motivation and personality. New York, NY: Harper \& Row.

Miller, L. E., \& Smith, K. L. (1983). Handling nonresponse issues. Journal of Extension, 21 (September/October), 45-50.

Moore, G.E., \& Camp, W.G. (1979). Why vocational agriculture teachers leave the profession: A comparison of perceptions. The Journal of the American Association of Teacher Educators in Agriculture, 20(3), 11-18.

Myers, D., Milne, A., Baker, K., \& Ginsburg, A. (1987). Student discipline and high school performance. Sociology of Education, 60, 18-33.

Palardy, M.J. (1995). Dealing with misbehavior: Two approaches. Journal of Instructional Psychology, 95, 135-141.

Pestello, F.G. (1989). Misbehavior in high school classrooms. Youth \& Society, 20(3), 290-306.

Rose, L.C., \& Gallup, A.M. (2000, September). The $32^{\text {nd }}$ annual Phi Delta Kappa/Gallup poll of the public's attitudes toward the public schools. Phi Delta Kappan, 82, 41-66. 
Stebbins, R. (1971). The meaning of disorderly behavior: Teacher definitions of a classroom situation. Sociology of Education, 44 (2), 217-236.

Supaporn, S. (2000). High school students' perspectives about misbehavior. Physical Educator, 57, 124-136.

Vernon, R.F., Bigna, S., \& Smith, M.L. (2001). Plagiarism and the web. Journal of Social Work Education, 37, 193-196. 